\title{
Thermococcus gammatolerans sp. nov., a hyperthermophilic archaeon from a deep-sea hydrothermal vent that resists ionizing radiation
}

Correspondence
Edmond Jolivet
ejolivet@Isu.edu

\author{
Edmond Jolivet, ${ }^{1} \dagger$ Stéphane L'Haridon, ${ }^{1}$ Erwan Corre, ${ }^{2}$ Patrick Forterre ${ }^{3}$ \\ and Daniel Prieur ${ }^{1}$
}

${ }^{1}$ UMR 6539, Centre National de la Recherche Scientifique et Université de Bretagne Occidentale, Technopôle Brest-Iroise, Place Nicolas Copernic, 29280 Plouzané, France

${ }^{2}$ UMR 7127, Station Biologique, CNRS et Université Pierre et Marie Curie, Place Georges Teissier, 29682 Roscoff Cedex, France

3UMR 8621, Institut de Génétique et Microbiologie, CNRS et Université Paris-Sud, Bât 409, 91405 Orsay Cedex, France

\begin{abstract}
Enrichments for anaerobic organotrophic hyperthermophiles were performed with hydrothermal chimney samples collected at the Guaymas Basin $\left(27^{\circ} 01^{\prime} \mathrm{N}, 111^{\circ} 24^{\prime} \mathrm{W}\right)$. Positive enrichments were submitted to $\gamma$-irradiation at a dose of $30 \mathrm{kGy}$. One of the resistant strains, designated strain $E J 3^{\top}$, formed regular motile cocci. The new strain grew between 55 and $95^{\circ} \mathrm{C}$, with an optimum growth temperature of $88^{\circ} \mathrm{C}$. The optimal $\mathrm{pH}$ for growth was $6 \cdot 0$, and the optimum $\mathrm{NaCl}$ concentration for growth was around $20 \mathrm{~g} \mathrm{I}^{-1}$. Strain $\mathrm{EJ} 3^{\top}$ was an obligately anaerobic heterotroph that utilized yeast extract, tryptone and peptone. Elemental sulfur or cystine was required for growth and reduced to hydrogen sulfide. The $\mathrm{G}+\mathrm{C}$ content of the genomic DNA was $51.3 \mathrm{~mol} \%$. As determined by $16 \mathrm{~S}$ rRNA gene sequence analysis, the organism was most closely related to Thermococcus celer, Thermococcus guaymasensis, Thermococcus hydrothermalis, Thermococcus profundus and Thermococcus gorgonarius. However, no significant homology was observed between them by DNA-DNA hybridization. The novel organism also possessed phenotypic traits that differ from those of its closest phylogenetic relatives. Therefore, it is proposed that this isolate, which constitutes the most radioresistant hyperthermophilic archaeon known to date, should be described as the type strain of a novel species, Thermococcus gammatolerans sp. nov. The type strain is $E J 3^{\top}\left(=\mathrm{DSM} 15229^{\top}=\mathrm{JCM} 11827^{\top}\right)$.
\end{abstract}

All members of the archaeal order Thermococcales are strictly anaerobic hyperthermophiles. The Thermococcaceae, the single family of this order, is composed of three genera, Thermococcus (Zillig et al., 1983), Pyrococcus (Fiala \& Stetter, 1986) and Palaeococcus (Takai et al., 2000). The main characteristics that distinguish these genera are their optimal growth temperature (between 75 and $88^{\circ} \mathrm{C}$ for Thermococcus and Palaeococcus species and between 96 and $100{ }^{\circ} \mathrm{C}$ for Pyrococcus members) and the clustering of their $16 \mathrm{~S}$ rRNA sequences as separate clades within the

Published online ahead of print on 29 November 2002 as DOI 10.1099/ijs.0.02503-0.

tPresent address: Dept of Biological Sciences, Louisiana State University and A \& M College, Baton Rouge, LA 70803, USA.

The GenBank accession number for the 16S rRNA sequence of Thermococcus gammatolerans strain EJ3 ${ }^{\top}$ is AF479014.

Data on the effect of temperature, $\mathrm{pH}$ and $\mathrm{NaCl}$ concentration on $\mathrm{EJ}^{\top}$ are available as supplementary material in IJSEM Online.
Thermococcales (Zillig \& Reysenbach, 2001). The genus Thermococcus includes at present 20 species that share similar physiological characteristics and can be divided into two groups on the basis of their $\mathrm{G}+\mathrm{C}$ content. Members of this genus grow heterotrophically by fermentation or sulfur respiration on a variety of organic compounds such as peptone, yeast extract, meat extract, casein, peptides, Casamino acids and starch. Some of them are able to grow in the absence of elemental sulfur, but this compound significantly stimulates their growth. Representative species of Thermococcus are widely distributed at deep-sea and shallow marine hydrothermal vents and have also been isolated from terrestrial thermal springs in New Zealand and deep oil reservoirs (Miroshnichenko et al., 2001; Zillig \& Reysenbach, 2001).

In the deep-sea hydrothermal environments of the East Pacific Rise, the polychaete Alvinella colonizes the walls of active chimneys and is exposed to natural radioactivity levels $\left({ }^{210} \mathrm{~Pb},{ }^{210} \mathrm{Po},{ }^{222} \mathrm{Rn}\right)$ a hundred times higher than 
received on the surface of the Earth (Cherry et al., 1992). Deep-sea hydrothermal vents could therefore represent an attractive milieu for studying the effects of ionizing radiation on thermophilic micro-organisms.

In this paper, a deep-sea hydrothermal vent chimney collected at the Guaymas Basin was used to isolate and characterize a novel Thermococcus species that resists high levels (30 kGy) of $\gamma$-irradiation.

The new organism was isolated from chimney samples collected by the submersible Nautile during the cruise 'Guaynaut' in 1991 in the Guaymas Basin [Gulf of California $\left(27^{\circ} 01^{\prime} \mathrm{N}, 111^{\circ} 24^{\prime} \mathrm{W}\right)$ ] at a depth of $2616 \mathrm{~m}$. Samples were immediately transferred into flasks filled with sterile reduced artificial seawater. The vials were then closed tightly with butyl rubber stoppers and stored at $4{ }^{\circ} \mathrm{C}$ until used for further experiments.

Anaerobic procedures were performed as described by Balch \& Wolfe (1976). Enrichment cultures were performed anaerobically in Hungate tubes containing $10 \mathrm{ml}$ YPS medium and incubated at $85^{\circ} \mathrm{C}$. The same conditions were used to cultivate routinely the reference strains and the new isolate (Table 1). The YPS medium contained per litre of distilled water: $35 \mathrm{~g}$ Sea Salts (Sigma), 3•46 g PIPES,
$1 \mathrm{~g}$ yeast extract, $4 \mathrm{~g}$ peptone, $5 \mathrm{~g}$ elemental sulfur, $0.5 \mathrm{~g}$ $\mathrm{NH}_{4} \mathrm{Cl}, 0 \cdot 35 \mathrm{~g} \mathrm{KH}_{2} \mathrm{PO}_{4}, 0 \cdot 2 \mathrm{~g} \mathrm{CaCl}_{2}, 6 \cdot 7 \mathrm{mg} \mathrm{FeCl} 3,2 \cdot 9 \mathrm{mg}$ $\mathrm{Na}_{2} \mathrm{WO}_{4}$ and $0.1 \mathrm{mg}$ resazurin. The $\mathrm{pH}$ was adjusted to $6 \cdot 8$ before autoclaving. Final anaerobiosis was achieved by adding sterile $5 \%(\mathrm{w} / \mathrm{v}) \mathrm{Na}_{2} \mathrm{~S} .9 \mathrm{H}_{2} \mathrm{O}$ to a final concentration of $0.025 \%$.

The positive enrichments obtained after 2 days incubation consisted of irregular motile and nonmotile coccoid cells. Aliquots of these cultures were irradiated at $30 \mathrm{kGy}$ on ice with a $\gamma$-ray source $\left({ }^{137} \mathrm{Cs}\right.$ ) at a rate of $60 \mathrm{~Gy} \min ^{-1}$ (Institut Curie, Orsay, France). After irradiation, cultures were transferred in YPS medium and incubated at $85^{\circ} \mathrm{C}$ for 3 days. Creamy colonies were obtained on YPS medium solidified with $1 \%(\mathrm{w} / \mathrm{v})$ gelrite and incubated in an anaerobic jar at $80^{\circ} \mathrm{C}$ (gas phase $\mathrm{N}_{2} / \mathrm{CO}_{2}, 80: 20,1$ bar) (Erauso et al., 1995). One colony was randomly picked and streaked on YPS-gelrite plates four times successively. The purity of the isolate (designated $\mathrm{EJ} 3^{\mathrm{T}}$ ) was checked microscopically by a serial dilution step.

After purification, the survival rate to $\gamma$-irradiation of isolate $\mathrm{EJ} 3^{\mathrm{T}}$ was evaluated and compared to that of 'Pyrococcus abyssi' GE5 ${ }^{\mathrm{T}}$ and Thermococcus stetteri DSM $5262^{\mathrm{T}}$. After irradiation at increasing doses, the surviving fraction was enumerated by the most probable number

Table 1. Characteristics that distinguish strain $E J 3^{\top}$ from its closest phylogenetic relatives

+, Positive; -, negative; ND, not determined; NR, not reported; R, required; S, stimulatory.

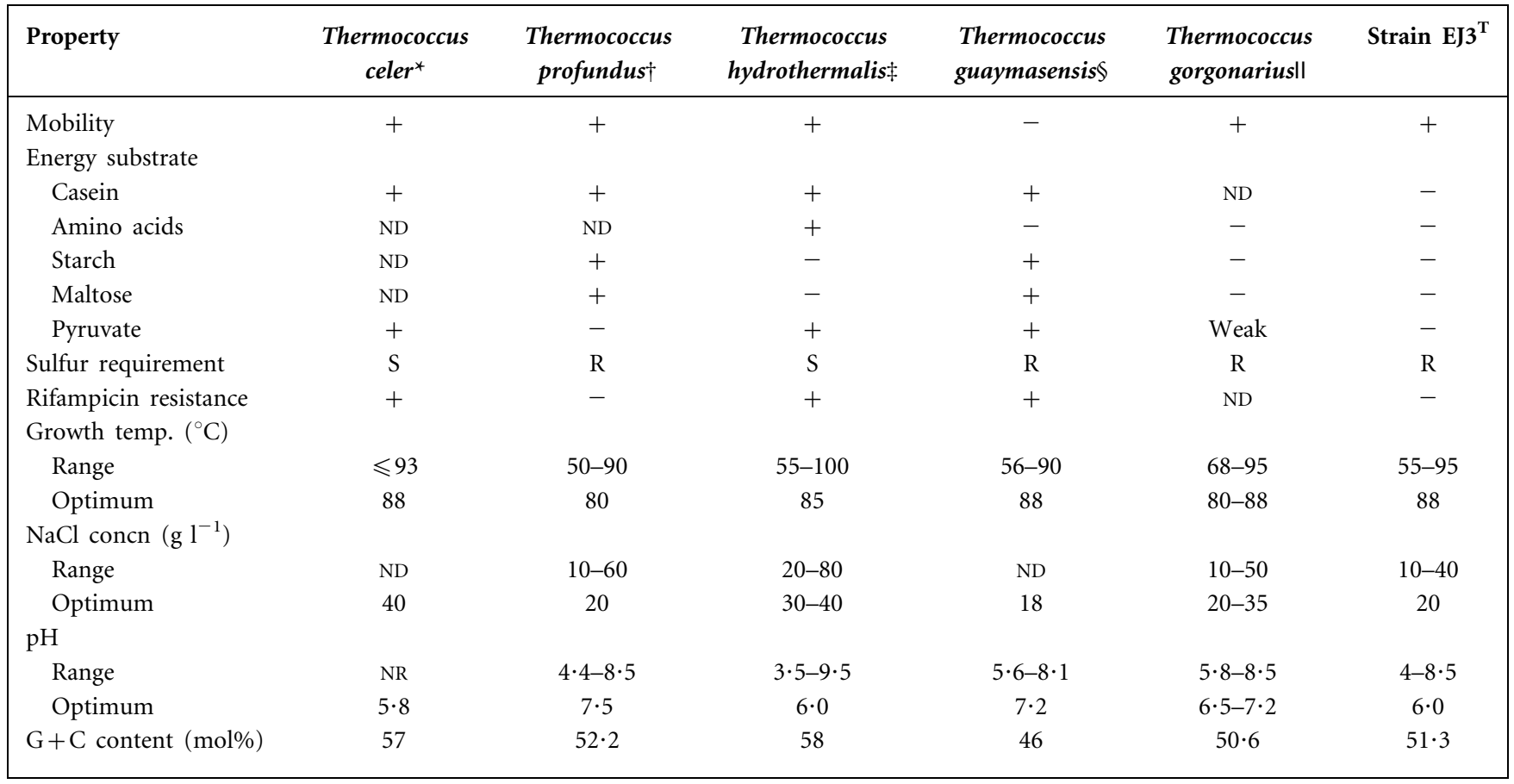

*Zillig et al. (1983).

$\dagger$ Kobayashi et al. (1994).

‡Godfroy et al. (1997).

§Canganella et al. (1998).

IIMiroshnichenko et al. (1998). 


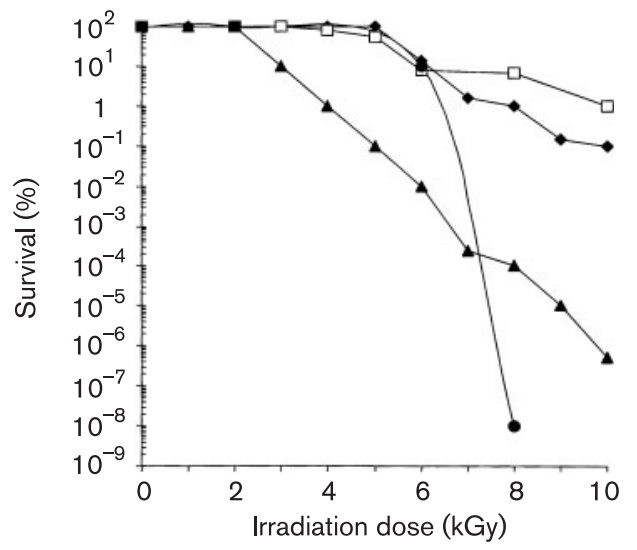

Fig. 1. Gamma-radiation survival curves. The new isolate, $E J 3^{\top}$ $(\square)$, was irradiated at the end of the exponential growth phase in YPS growth medium under anaerobic conditions. These values are a mean of two independent experiments. Survival

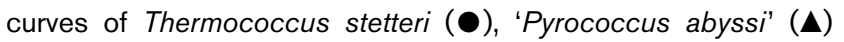
and Deinococcus radiodurans $(\boldsymbol{})$ were taken from Kopylov et al. (1993), Battista (1997) and Gérard et al. (2001).

technique. The new isolate was found to resist $3 \mathrm{kGy}$ without loss of cultivatability (Fig. 1). Contrary to ' $P$. abyssi' and Thermococcus stetteri, its survival curve was close to that determined for Deinococcus radiodurans (Battista, 1997). Like D. radiodurans, a fraction of an end-exponential culture of the new isolate was able to grow after irradiation at $30 \mathrm{kGy}$. When tested for this ability, cells of 'P. abyssi' and Thermococcus stetteri could not be cultivated after irradiation doses exceeding 11 and $18 \mathrm{kGy}$, respectively (data not shown).

Cells of strain $\mathrm{EJ} 3^{\mathrm{T}}$ formed regular cocci occurring singly or in pairs. They were motile by means of polar flagella (Fig. 2).

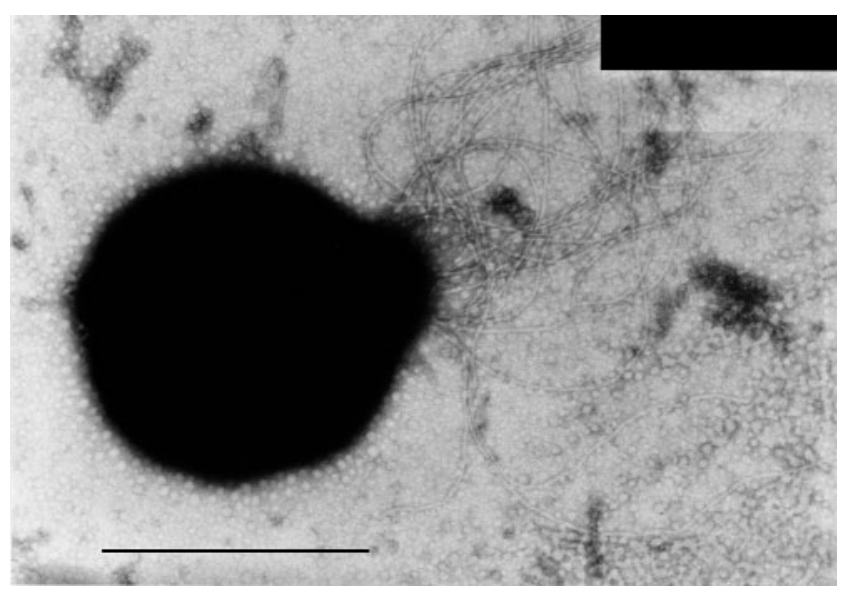

Fig. 2. Electron micrograph of a negatively stained cell of strain $E J 3^{\top}$ prepared as previously described (L'Haridon et al., 1998). Bar, $1 \mu \mathrm{m}$.
The diameter of the cells ranged from 0.6 to $1.4 \mu \mathrm{m}$ and remained relatively constant around $1 \mu \mathrm{m}$ under optimal growth conditions. Cells appeared to divide by constriction.

Unless otherwise stated, YPS medium was used for growth experiments. The optimal $\mathrm{pH}$ for growth was determined at $85^{\circ} \mathrm{C}$ as described by Marteinsson et al. (1999). To determine the optimal $\mathrm{NaCl}$ concentration for growth, increasing concentrations of $\mathrm{NaCl}$ were added to a medium that contained per litre of distilled water: $10 \cdot 77 \mathrm{~g}$ $\mathrm{MgCl}_{2} .6 \mathrm{H}_{2} \mathrm{O}, 3.97 \mathrm{~g} \mathrm{Na}_{2} \mathrm{SO}_{4}, 0.20 \mathrm{~g} \mathrm{NaHCO}_{3}, 0.09 \mathrm{~g} \mathrm{KBr}$, $0.025 \mathrm{SrCl}_{2} .6 \mathrm{H}_{2} \mathrm{O}, 0.671 \mathrm{~g} \mathrm{KCl}, 0.26 \mathrm{~g} \mathrm{H}_{3} \mathrm{BO}_{3}, 0.003 \mathrm{~g}$ $\mathrm{NaF}, 3.46 \mathrm{~g}$ PIPES, $1 \mathrm{~g}$ yeast extract, $4 \mathrm{~g}$ peptone, $5 \mathrm{~g}$ elemental sulfur, $0.5 \mathrm{~g} \mathrm{NH}_{4} \mathrm{Cl}, 0.35 \mathrm{~g} \mathrm{KH}_{2} \mathrm{PO}_{4}, 0.2 \mathrm{~g} \mathrm{CaCl}_{2}$, $6.7 \mathrm{mg} \mathrm{FeCl} 3,2.9 \mathrm{mg} \mathrm{Na} 2 \mathrm{WO}_{4}$ and $0.1 \mathrm{mg}$ resazurin. The $\mathrm{pH}$ was adjusted to $6 \cdot 8$ before autoclaving. Final anaerobiosis was achieved by adding sterile $5 \%(\mathrm{w} / \mathrm{v}) \mathrm{Na}_{2} \mathrm{~S} .9 \mathrm{H}_{2} \mathrm{O}$ to a final concentration of $0 \cdot 025 \%$. All the experiments were performed in duplicate.

Under these conditions, isolate $\mathrm{E} 3^{\mathrm{T}}$ grew between 55 and $95^{\circ} \mathrm{C}$ and the optimum temperature for growth was $88^{\circ} \mathrm{C}$. No growth was detected at 50 and $96^{\circ} \mathrm{C}$. The optimum pH was between $5 \cdot 5$ and $6 \cdot 5$. No growth occurred at $\mathrm{pH} 3.0$ and 8.5 . The optimum $\mathrm{NaCl}$ concentration was $20 \mathrm{~g} \mathrm{l}^{-1}$. No growth was detected at $\mathrm{NaCl}$ concentrations of 0 and $40 \mathrm{~g} \mathrm{l}^{-1}$. Under optimal growth conditions (temperature, $\mathrm{pH}$ and $\mathrm{NaCl}$ ), the doubling time of the isolate was around $95 \mathrm{~min}$. See the supplementary data available in IJSEM Online at http://ijs.sgmjournals.org

The ability of the isolate to use single carbon sources for growth was tested at optimal growth temperature on YPS medium in which yeast extract and peptone were omitted. A filter-sterilized solution of vitamins $\left(10 \mathrm{ml} \mathrm{l}^{-1}\right)$ (Widdel \& Bak, 1992) was added and $\mathrm{N}_{2}$ was used as headspace. Since no growth was observed in aerated conditions and in mineral medium supplemented with vitamins and $\mathrm{a} \mathrm{H}_{2} / \mathrm{CO}_{2}$ $(80: 20)$ headspace, strain $\mathrm{EJ} 3^{\mathrm{T}}$ appeared to be an obligately anaerobic organotroph. Under anaerobic conditions, $\mathrm{S}^{\circ}$ and cystine were necessary for growth and reduced to hydrogen sulfide. No growth was detected in the presence of thiosulfate $(10 \mathrm{mM})$, sulfate $(20 \mathrm{mM})$ or sulfite $(10 \mathrm{mM})$. Significant growth was observed on yeast extract, peptone and tryptone (all at $0 \cdot 2 \%, \mathrm{w} / \mathrm{v})$. Strain $\mathrm{EJ} 3^{\mathrm{T}}$ was not able to grow on a mixture of 20 amino acids. No growth was observed on Casamino acids, acetate, succinate, propionate, pyruvate (all at $0 \cdot 2 \%, \mathrm{w} / \mathrm{v}$ ), vitamins, gelatin $(0.5 \%, \mathrm{w} / \mathrm{v})$, sucrose, cellobiose, lactose, maltose, glycogen, xylose or starch (all at $0.5 \%, \mathrm{w} / \mathrm{v}$ ). No growth was observed in the basal medium using $\mathrm{H}_{2} / \mathrm{CO}_{2}(80: 20 ; 200 \mathrm{kPa})$ as headspace.

Isolate $\mathrm{EJ} 3^{\mathrm{T}}$ was resistant to chloramphenicol, ampicillin, penicillin, kanamycin, vancomycin and streptomycin at a concentration of $150 \mu \mathrm{g} \mathrm{ml}^{-1}$, but this isolate was sensitive to rifampicin at the same concentration. Thermotoga maritima, used as control, exhibited the expected pattern of antibiotic susceptibility at $80^{\circ} \mathrm{C}$ (Huber et al., 1986). 
The $\mathrm{G}+\mathrm{C}$ content of the DNA of isolate $\mathrm{E} J 3^{\mathrm{T}}$ determined by the thermal denaturation method as described by Jeanthon et al. (1998) was $51 \cdot 3 \mathrm{~mol} \%$.

16S rDNA was amplified by PCR with Taq polymerase (Promega), using the genomic DNA from strain $\mathrm{EJ}^{\mathrm{T}}$ as template and two primers: one specific for archaea (4F primer: 5'-TCC GGT TGA TCC TGC CGG-3') and one universal (1492R primer: $5^{\prime}$-GGT TAC CTT GTT ACG ACT $\left.\mathrm{T}-3^{\prime}\right)$. PCR reactions were typically carried out in a volume of $50 \mu \mathrm{l}$ containing 50-100 ng template, $100 \mathrm{ng}$ of each of the two specific primers, $250 \mu \mathrm{M}$ dNTP, $1 \pm 5 \mathrm{mM} \mathrm{MgCl}_{2}$, $1 \times$ buffer (Promega) and 2.5 U polymerase. The different steps of PCR were as follows: $5 \mathrm{~min}$ at $95^{\circ} \mathrm{C}$; then 25 cycles of $1.5 \mathrm{~min}$ at $95^{\circ} \mathrm{C}, 1.5 \mathrm{~min}$ at $53^{\circ} \mathrm{C}$ and $2.5 \mathrm{~min}$ at $72^{\circ} \mathrm{C}$; then finally a polymerization step of $8 \mathrm{~min}$ at $72^{\circ} \mathrm{C}$. PCR products were cloned in vector PCRII2.1 and several clones were sequenced to ensure the sequence quality, using Texas-red-labelled primers, a Thermosequenase kit (RPN 2444; Amersham) and a Vistra 725 automated sequencer. Phylogenetic analysis of the $16 \mathrm{~S}$ rDNA gene sequence was realized as described by Corre et al. (2001). The sequence of strain $\mathrm{EJ}^{\mathrm{T}}$ has been deposited in the GenBank database under accession number AF479014.

The $16 \mathrm{~S}$ rDNA sequence analysis placed strain $\mathrm{EJ} 3^{\mathrm{T}}$ within the genus Thermococcus (Fig. 3). The highest levels of similarity between the $16 \mathrm{~S}$ rDNA sequence of $\mathrm{EJ}^{\mathrm{T}}{ }^{\mathrm{T}}$ and those of other Thermococcus species were as follows: Thermococcus gorgonarius, 98.9\%; Thermococcus celer and Thermococcus guaymasensis, 98.4\%; Thermococcus profundus, $98.3 \%$; and Thermococcus hydrothermalis, 97.6\%, Pyrococcus furiosus, $96 \cdot 4 \%$, and Palaeococcus ferrophilus, $94 \cdot 0 \%$.

Considering the high levels of similarity (more than $98 \%$ ) existing between strain $\mathrm{EJ}^{\mathrm{T}}$ and Thermococcus gorgonarius, Thermococcus celer, Thermococcus guaymasensis, Thermococcusprofundus and Thermococcus hydrothermalis, quantitative DNA-DNA hybridizations between the isolate and its closest relatives were performed as described by Jeanthon et al. (1998). When strain $\mathrm{EJ} 3^{\mathrm{T}}$ was used as the labelled probe, the levels of DNA reassociation were as follows: Thermococcus gorgonarius, 18.3\%; Thermococcus celer, 19.2 \%; Thermococcus guaymasensis, $23 \cdot 2 \%$; Thermococcus profundus, 19.5\%; and Thermococcus hydrothermalis, $22 \cdot 1 \%$.

When a number of different taxonomic parameters were compared, strain $\mathrm{EJ} 3^{\mathrm{T}}$ differed from its closest phylogenetic relatives (Table 1). It differs from most of them by its temperature range for growth and its inability to grow on casein and pyruvate. Moreover, strain $\mathrm{EJ}^{\mathrm{T}}{ }^{\mathrm{T}}$ differs strongly from Thermococcus celer, Thermococcus hydrothermalis and Thermococcus guaymasensis in its $\mathrm{G}+\mathrm{C}$ content and its rifampicin sensitivity, and from Thermococcus gorgonarius in its salinity range and its optimum $\mathrm{pH}$ for growth. Finally, it can be distinguished from Thermococcus profundus by its salinity range and its inability to use starch and maltose.

On the basis of its phenotypical and genetic characteristics, strain $\mathrm{EJ}^{\mathrm{T}}$ represents a novel species within the genus Thermococcus. We propose to name it Thermococcus gammatolerans according to its high degree of tolerance to $\gamma$-irradiation.

\section{Description of Thermococcus gammatolerans sp. nov.}

Thermococcus gammatolerans (ga.mma.to'le.rans. gamma referring to gamma rays used as selection pressure for isolation; L. pres. part. tolerans tolerating; N.L. adj. gammatolerans referring to its ability to tolerate high levels of $\gamma$-rays).

Cells are cocci (diameter $0 \cdot 6-1 \cdot 4 \mu \mathrm{m}$ ) that are motile by the presence of polar flagella. Cell division occurs by constriction. Obligately anaerobic. Growth occurs at $55-95^{\circ} \mathrm{C}$, and the optimum temperature is $88^{\circ} \mathrm{C}$. Grows optimally in the presence of $20 \mathrm{~g} \mathrm{NaCl}^{-1}$ and at $\mathrm{pH}$ around $6 \cdot 0$. Obligately organotrophic. Grows preferentially on proteolysis products such as yeast extract, tryptone and peptone. Does not grow on Casamino acids, acetate, succinate, propionate,

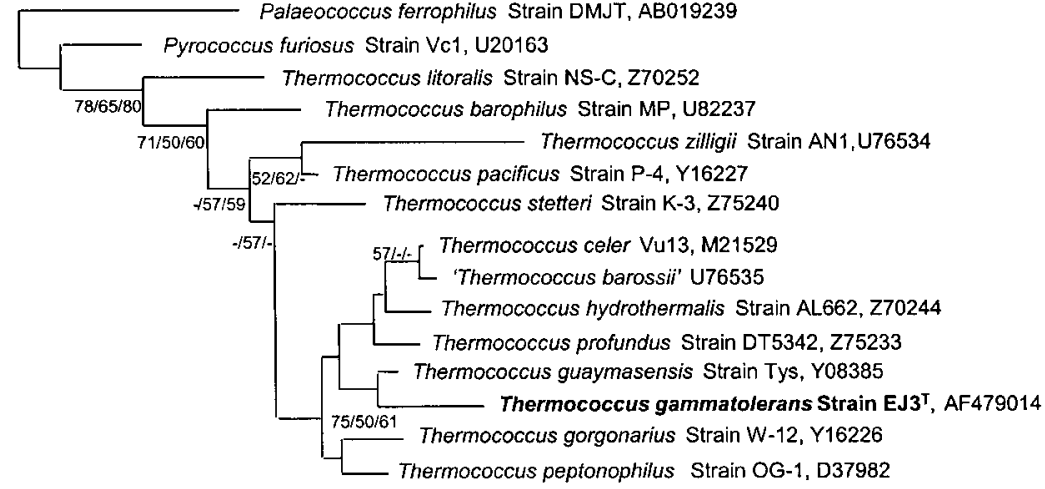

0.01
Fig. 3. Phylogenetic position of strain $E J 3^{\top}$ (in boldface) amongst some representatives of the family Thermococcaceae; 1320 nucleotides were used in the phylogenetic analysis. Numbers after the strain names are GenBank accession numbers of $16 \mathrm{~S}$ rDNA sequences. The topology shown is the tree obtained using the neighbour-joining method (Jukes and Cantor distance correction). Numbers at the nodes refer to the bootstrap values (100 replicates) in distance, maximumlikelihood and maximum-parsimony analyses, respectively. Bootstrap values below $50 \%$ were not represented or represented by dashes. The scale bar represents the expected number of changes per sequence position. 
pyruvate, gelatin, glucose, maltose or starch. Sulfur or cystine are necessary for growth and reduced to hydrogen sulfide. Thiosulfate, sulfate and sulfite are not used as electron acceptors. Resistant to chloramphenicol, ampicillin, penicillin, kanamycin, vancomycin and streptomycin at $150 \mu \mathrm{g} \mathrm{ml}^{-1}$, but sensitive to $150 \mu \mathrm{g}$ rifampicin $\mathrm{ml}^{-1}$. The results of $16 \mathrm{~S}$ rDNA sequence comparisons place Thermococcus gammatolerans in the Thermococcales.

The type strain, EJ $3^{\mathrm{T}}\left(=\mathrm{DSM} 15229^{\mathrm{T}}=\mathrm{JCM} 11827^{\mathrm{T}}\right)$, was isolated from an active chimney recovered from a hydrothermal site in Guaymas Basin $\left(27^{\circ} 01^{\prime} \mathrm{N}\right.$ and $\left.111^{\circ} 24^{\prime} \mathrm{W}\right)$ at a depth of $2616 \mathrm{~m}$.

\section{Acknowledgements}

We thank Dr Vincent Favaudon for the use of the ${ }^{137} \mathrm{Cs} \gamma$-ray source (Institut Curie, Orsay, France). We also thank Dr Christian Jeanthon for critical reading of the manuscript and for useful discussions.

\section{References}

Balch, W. E. \& Wolfe, R. S. (1976). New approach to the cultivation of methanogenic bacteria: 2-mercaptoethane-sulfonic acid (HSCoM)-dependent growth of Methanobacterium ruminantium in a pressurized atmosphere. Appl Environ Microbiol 32, 781-791.

Battista, J. R. (1997). Against all odds: the survival strategies of Deinococcus radiodurans. Annu Rev Microbiol 18, 203-224.

Canganella, F., Jones, W. J., Gambacorta, A. \& Antranikian, G. (1998). Thermococcus guaymasensis sp. nov. and Thermococcus aggregans sp. nov., two novel thermophilic archaea isolated from the Guaymas Basin hydrothermal vent site. Int J Syst Bacteriol 48, 1181-1185.

Cherry, R. D., Desbruyères, M., Heyraud, M. \& Nolan, C. (1992). High levels of natural radioactivity in hydrothermal vent polychaetes. C R Acad Sci Paris III, 21-26.

Corre, E., Reysenbach, A. L. \& Prieur, D. (2001). Epsilonproteobacterial diversity from a deep-sea hydrothermal vent on the Mid-Atlantic Ridge. FEMS Microbiol Lett 205, 329-335.

Erauso, G. \& Prieur, D. (1995). Plate cultivation technique for strictly anaerobic, thermophilic, sulfur-metabolizing archaea. In Archaea: a Laboratory Manual, vol. 3, pp. 25-29. Edited by E. M. Fleischmann, A. R. Place, F. T. Robb \& H. J. Schreider. Cold Spring Harbor, NY: Cold Spring Harbor Laboratory.

Fiala, G. \& Stetter, K. (1986). Pyrococcus furiosus sp. nov. represents a new genus of marine heterotrophic archaebacteria growing optimally at $100{ }^{\circ} \mathrm{C}$. Arch Microbiol 145, 338-349.

Gérard, E., Jolivet, E., Prieur, D. \& Forterre, P. (2001). DNA protection is not involved in the radioresistance of the hyperthermophilic archaea Pyrococcus abyssi and Pyrococcus furiosus. Mol Genet Genom 266, 72-78.

Godfroy, A., Lesongeur, F., Raguénès, G., Quérellou, J., Antoine, E., Meunier, J.-R., Guezennec, J. \& Barbier, G. (1997). Thermococcus hydrothermalis sp. nov., a new hyperthermophilic archaeon isolated from a deep-sea hydrothermal vent. Int J Syst Bacteriol 47, 622-626.

Huber, R. J., Langworthy, T. A., Konig, H., Thomm, M., Woese, C. R., Sleytr, U. B. \& Stetter, K. O. (1986). Thermotoga maritima sp. nov. represents a new genus of unique extremely thermophilic eubacteria growing up to $90^{\circ} \mathrm{C}$. Arch Microbiol 144, 324-333.

Jeanthon, C., L'Haridon, S., Reysenbach, A. L., Vernet, M., Messner, P., Sleytr, U. B. \& Prieur, D. (1998). Methanococcus infernus sp. nov., a novel hyperthermophilic lithotrophic methanogen isolated from a deep-sea hydrothermal vent. Int J Syst Bacteriol 48, 913-919.

Kobayashi, T., Kwak, Y. S., Akiba, T., Kudo, T. \& Horikoshi, K. (1994). Thermococcus profundus sp. nov., a new hyperthermophilic archaeon isolated from a deep-sea hydrothermal vent. Syst Appl Microbiol 17, 232-236.

Kopylov, V. M., Bonch-Osmolovskaya, E. A., Svetlichnyi, V. A., Miroshnicheko, M. L. \& Skobkin, V. S. (1993). Gamma-irradiation resistance and UV-sensitivity of extremely thermophilic archaebacteria and eubacteria. Mikrobiologiya 62, 90-95.

L'Haridon, S., Cilia, V., Messner, P., Raguénès, G., Gambacorta, A., Sleytr, U. B., Prieur, D. \& Jeanthon, C. (1998). Desulfurobacterium thermolithotrophum gen. nov., sp. nov., a novel autotrophic, sulphurreducing bacterium isolated from a deep-sea hydrothermal vent. Int J Syst Bacteriol 48, 701-711.

Marteinsson, V. T., Birrien, J.-L., Reysenbach, A.-L., Vernet, M., Marie, D., Gambacorta, A., Messner, P., Sleytr, U. \& Prieur, D. (1999). Thermococcus barophilus sp. nov., a new barophilic and hyperthermophilic archaeon isolated under high hydrostatic pressure from a deep-sea hydrothermal vent. Int J Syst Bacteriol 49, 351-359.

Miroshnichenko, M. L., Gongadze, G. M., Rainey, F. A., Kostyukova, A. S., Lysenko, A. M., Chernyh, N. A. \& Bonch-Osmolovskaya, E. A. (1998). Thermococcus gorgonarius sp. nov. and Thermococcus pacificus sp. nov.: heterotrophic extremely thermophilic archaea from New Zealand submarine hot vents. Int J Syst Bacteriol 48, 23-29.

Miroshnichenko, M. L., Hippe, H., Stackebrandt, E., Kostrinika, N. A., Chernyh, N. A., Jeanthon, C., Nazina, T. N., Belyaev, S. S. \& Bonch-Osmolovskaya, E. A. (2001). Isolation and characterization of Thermococcus sibiricus sp. nov., from western siberia hightemperature oil reservoir. Extremophiles 5, 85-91.

Takai, K., Sugai, A., Itoh, T. \& Horikoshi, K. (2000). Palaeococcus ferrophilus gen. nov., sp. nov., a barophilic, hyperthermophilic archaeon from a deep-sea hydrothermal vent chimney. Int J Syst Evol Microbiol 50, 489-500.

Widdel, F. \& Bak, F. (1992). Gram-negative mesophilic sulfatereducing bacteria. In The Prokaryotes, 2nd edn, pp. 3352-3378. Edited by A. Balows, H. G. Trüper, M. Dworkin, W. Harder \& K. H. Shleifer. New York: Springer.

Zillig, W. \& Reysenbach, A.-L. (2001). Class IV. Thermococci class. nov. In Bergey's Manual of Systematic Bacteriology, 2nd edn, vol. 1, pp. 342-346. Edited by D. R. Boone \& R. W. Castenholz. New York: Springer.

Zillig, W., Holz, I., Janekovic, D., Schäfer, W. \& Reiter, W. D. (1983). The archaebacterium Thermococcus celer represents a novel genus within the thermophilic branch of the archaebacteria. Syst Appl Microbiol 4, 88-94. 